Francesc Trillas 
The Public-Private Sector Research Center is a Research Center based at IESE Business School. Its mission is to develop research that analyses the relationships between the private and public sectors primarily in the following areas: regulation and competition, innovation, regional economy and industrial politics and health economics.

Research results are disseminated through publications, conferences and colloquia. These activities are aimed to foster cooperation between the private sector and public administrations, as well as the exchange of ideas and initiatives.

The sponsors of the SP-SP Center are the following:

- Accenture

- Ajuntament de Barcelona

- Caixa Manresa

- Cambra Oficial de Comerç, Indústria i Navegació de Barcelona

- Consell de l'Audiovisual de Catalunya

- Departament d' Economia i Finances de la Generalitat de Catalunya

- Departament d' Innovació, Universitats i Empresa de la Generalitat de Catalunya

- Diputació de Barcelona

- Endesa

- Fundació AGBAR

- Garrigues

- Mediapro

- Microsoft

- Sanofi Aventis

- ATM, FGC y TMB

The contents of this publication reflect the conclusions and findings of the individual authors, and not the opinions of the Center's sponsors. 


\title{
ELECTRICITY AND TELECOM REFORMS IN THE EU: INSIGHTS FROM THE ECONOMICS OF FEDERALISM
}

\author{
Francesc Trillas ${ }^{1}$
}

\begin{abstract}
The economics of federalism is a broad discipline with more than five decades of experience. It may shed light on how regulatory jurisdiction is allocated in EU electricity and telecommunications markets. Specifically, this paper assesses the evolution of reform up to and including the third EU packages, which continue the liberalization and integration process in these markets. Liberalization has been accompanied by gradual harmonization of national markets to overcome resistance to competitive forces. Less steps than necessary have been undertaken to promote market integration. Positive and normative reasons remain, however, for the participation of national or even regional/local powers. Vertical institutional cooperation will remain a necessary condition for a sound regulatory framework, but cooperation may sometimes be inhibited by distributive considerations.
\end{abstract}

Classification L50, L94, L96, L97, K23, H77.

Keywords: federalism, regulation, electricity, telecommunications.

\footnotetext{
${ }^{1} \mathrm{UAB}$ and Public-Private Sector Research Center, IESE. Acknowledge to the Spanish Ministry of Science and Innovation under EC02008-05155.
} 


\section{ELECTRICITY AND TELECOM REFORMS IN THE EU: INSIGHTS FROM THE ECONOMICS OF FEDERALISM}

\section{Introduction}

The allocation of regulatory tasks in network industries across the vertical structure of government is a key issue that must be addressed, coinciding with gradual liberalization. In the European Union, national markets have been gradually harmonized since the 1990s and the new regulatory packages that are being debated include the creation of some form of panEuropean telecommunications and energy regulators. At the same time, jurisdictional conflicts have intensified, for example, in the discussion concerning the regulatory holidays for nextgeneration broadband between Germany and the European Commission, or the jurisdictional controversy between Spain and the European Commission concerning the conditions for the failed takeover of Endesa by E-On.

There is a well-documented historical trend by which the regulation of utilities has moved up in the vertical chain of government, starting in the early $20^{\text {th }}$ century, from the local to the state level in the United States ${ }^{1}$ and other jurisdictions. ${ }^{2}$ However, in the United States, the bulk of regulation is still performed at the state level and has not moved much further up towards the federal level, although the federal regulatory agencies created in the New Deal era have played an increasing role, first in regulating interstate issues and in the recent past, in promoting and actively overseeing liberalization. Meanwhile, significant intervention still persists at the local level, as illustrated by the role of municipal powers in electricity distribution or broadband promotion. Decentralized powers are under significant pressure to intervene in regulated network industries, for at least three reasons (see Troesken, 1996):

a) The physical deployment of networks depends on the rights of way for which local powers are often naturally responsible.

b) Regulatory policies are locally salient.

c) Interest groups find it relatively easy at the local level to organize themselves to influence these policies in a variety of directions.

\footnotetext{
${ }^{1}$ See Troesken (1996), Hausman and Neufeld (1991, 1999, 2004), Neufeld (2008).

${ }^{2}$ Although in most other jurisdictions, the move to the national-state level involved the creation of state-owned and (mostly, although not universally, especially in electricity) national vertically-integrated firms.
} 
If local powers were responsible for most of these policies (for example, for setting regulated tariffs), they would face the typical commitment problem in the presence of sunk investments (see, for example, Levine et al., 2005, and references therein). A key question then is how to organize regulation taking into account the constraints faced at each level of government.

Liberalization processes in the United States and the EU add a further layer of complexity relative to monopoly regulation. As some authors have characterized the liberalization process in network industries as a "long and winding road," ${ }^{3}$ a not insignificant ingredient of such conditions is the relationship between the different government levels. If anything, the introduction of competition increases institutional diversity (see Moore, 2002).

The organization of government may not always coincide with market boundaries or with the boundaries of firms. As Woroch (1990) argues, "when multiple regulators are unavoidable, boundaries between them should divide areas and services that exhibit low cross-elasticities of demand and supply. Such 'bright lines' have become less attainable with recent developments in telephony." And "how governments divide up the industrial landscape may be vastly different from how business chooses to organize." In telecommunications and electricity, there are substantial differences in the interaction between competitive potential and geographical scope. In electricity, distribution and supply are mainly local goods (although sales of bulk power to large industrial consumers or multi-outlet companies such as supermarkets can be regional/national) and transmission and generation are potentially regional in scope; transmission and distribution are regulated natural monopolies with a different geographic scope. An important difference with telecommunications is that long-distance communications are also supra-local but are potentially competitive.

The relationship between regulation and investment is another key aspect of the debate. For example, some commentators argue that too much regulatory diversity discourages investment because it introduces costs related to red tape and uncertainty. ${ }^{4}$ But others (such as Weingast and his co-authors in their theory of market-preserving federalism reviewed in Section 2) argue that decentralization introduces a variety of veto points which stop the predatory tendencies associated with Leviathan and restricts the information and authority available to central powers, thereby contributing to reinforcing commitment (to not expropriate investments).

However, decentralization as an attempt to reduce the role of state intervention (as advocated in the Reagan era in the United States) may have the problem of reducing the scope for good as well as for bad policies: as is well known in the literature on reform in developing countries, the further veto points contributed by decentralization favour the status quo. This may be good if the status quo implies preserving the value of investments, but it may be bad if the status quo implies stopping a potentially welfare increasing market expansion or liberalization process. Both the new political economy of federalism and the experience of United States electricity suggest that decentralization (at the state or member state level) is better at providing commitment for investment than at accommodating market reforms.

There are not many academic contributions in economics to the federalism debate in the field of the regulation of network industries ${ }^{5}$ (although there are generic references to "regulation" in

\footnotetext{
${ }^{3}$ Armstrong and Sappington (2006).

${ }^{4}$ On the compliance costs of overlapping or duplicated regulation, see mentions to it by Kovacic (2007) and Spector (2007).

${ }^{5}$ There are very interesting contributions to federalism in United States network industries from historians (Troesken, 1996), legal scholars (Weiser, 2001, 2003) and political scientists (Teske, 2004).
} 
the federalism literature, such as in Oates, 1999, and Easterbrook, 1983), as compared to the literature on fiscal or environmental policy. There are some informal discussions (Smith, 2000; Brennan, 2003; Seabright, 1998), some empirical work (Humplick and Estache, 1995), a few very general theoretical models that can be applied to any industry or policy (Seabright, 1996; Caillaud et al., 1996), and very few models applied to network industries (Laffont and Pouyet, 1994; Bardhan and Mookherjee, 2006; Woroch, 1990; Lehman and Weismann, 2000).

Existing theories or empirical work on economic federalism, which are reviewed in the next Section, do not allow for a general conclusion in favour of a clear assignment of centralized or decentralized regulation, and the solutions may be space or sector specific. However, decisions on jurisdictional allocation of regulatory responsibilities are a matter of discussion in the EU, ${ }^{6}$ and the debate there would benefit from an understanding of old and new considerations on economic federalism.

This article explores first in Section 2 to what extent the existing literature on economic (mainly fiscal) federalism is applicable to network industries. Section 3 summarizes past and proposed European reforms of electricity and telecommunications against the background of the literature on the economics of federalism. Section 4 presents a concluding discussion.

\section{The Regulation of Network Industries and the Economics of Federalism}

The theoretical and empirical literature on economic federalism ${ }^{7}$ provides few clear-cut prescriptions as to the appropriate jurisdictional location of regulatory decisions, although it contributes a variety of insights that may be useful in specific settings. In general, centralization performs better when there are jurisdictional spillovers and when there are coordination issues and product and "policy" economies of scale. Centralized decision-making does not necessarily imply uniform decision-making (as in electricity in Great Britain), although decentralization reinforces a commitment to geographic differentiation. Decentralization is also favoured when knowledge of local demand or cost (including political transaction costs) conditions is important. Moreover, the type of decentralization is often crucial in the arguments. Not surprisingly, the empirical evidence finds little overall significant evidence of decentralization dominating centralization or vice versa. Further details on the literature are given below, but the focus here is on how the arguments affect the regulation and other public policies related to network industries. The literature review starts with the traditional, "first-generation" fiscal federalism studies, and then analyzes issues addressed by "second-generation" studies, concerned with contract theory and political economy issues.

\footnotetext{
${ }^{6}$ For example, Wilks and McGowan (1995) discussed the idea of creating an independent (from the governments and the Commission) European Cartel Office, and dismissed it on the grounds that it would lose the economies of coordination with other policy goals that the Commission provides, and it would be marginalized and less effective than the Commission.

${ }^{7}$ For excellent surveys of the general literature on federalism, see Oates (1999) and Treisman (2007). Several definitions of federalism are provided by Riker (1964), Rubinfeld (1997), and Treisman (2007).
} 


\subsection{First-generation Fiscal Federalism: Regulatory Competition, Heterogeneity, Scale and Laboratory Federalism}

"Laboratory federalism" is the concept used to portray the situation where a number of decentralized jurisdictions experiment with different options to solve the same problem in the face of uncertainty, so that all the decentralized units can learn. It is an idea originally attributed to Justice Brandeis of the United States Supreme Court. To some extent, this is what has happened with regulatory reform in the recent past: some jurisdictions have learned from others' experiences. For example, the California crisis in 2000 has influenced subsequent developments in United States electricity. Similarly, the functional separation of the incumbent's wireline telecommunications broadband network in the United Kingdom has been taken as an example by the European Commission to discuss the possible adoption of related models in the rest of the EU. However, in a decentralized federation where jurisdictions spontaneously engage in innovation, there will be too few innovations because of the public good nature of information that reduces uncertainty levels. ${ }^{8}$

Of course, the federal authorities and the states can derive the wrong lessons from experiments: the interested parties will highlight those elements of the experiments that best suit their interests. As in any public policy decision-making process, the outcome will depend on a number of political economy dimensions.

Competition between states to attract mobile factors may select good policies in equilibrium, but only under certain conditions. For example, competition between jurisdictions becomes less effective as the size of the legislating jurisdiction increases. ${ }^{9}$ The classical Tiebout (1959) model of fiscal competition is a revelation mechanism exercise where citizens reveal their preferences for local public goods by moving around localities that offer different combinations of taxation and public goods. Easterbrook (1983) translates the argument to general regulatory policies and concludes that "one need not think of states as laboratories, as Justice Brandeis did, to know that the pressures of exit and voice cause governments to search for laws that strike an adequate balance between favours to interest groups and benefits to other residents. The greatest threat to consumers' welfare is not states, and their competition, but a uniform national regimen that stifles the power of exit -that is, a monopoly of lawmaking." However, the conditions required for inter-jurisdictional competition to be efficient in economic terms are strong. ${ }^{10}$

In most network industries, capital is fixed and sunk and therefore mostly immobile. Accordingly, the argument that capital mobility induces good regulatory policies cannot be made in the sense that the regulated industries' capital will not move as a result of bad policies. But in theory it can still be made in the indirect sense that other businesses (e.g. businesses not in the regulated sector, but who intensively use inputs from a regulated industry) and individuals can move as a result of an environment of bad performance of the regulated sector caused by inefficient regulation.

\footnotetext{
${ }^{8}$ The degree of innovation contributed by the decentralized units will be lower than optimal because they pay the full costs of the innovative activities and will only reap part of the benefits. It would be better then to organize the localized experiments centrally.

${ }^{9}$ Casual empiricism reveals that it is precisely in large countries where sub-central units are large (United States, Canada, Australia, Argentina, India) that regulation is decentralized (see also Beato and Laffont, 2002). This suggests that the jurisdictional competition rationale has not played an important role in the evolution of regulation in these countries.

${ }^{10}$ Spector (2007) cites recent negative empirical results for the states competition theory based on the Tiebout model.
} 
Inter-jurisdictional competition for mobile capital may, however, only favour initially rich regions if the initial heterogeneity is too high (see Treisman, 2007). If capital is more mobile than labour, and competition for capital takes place at least in part through low taxes, this may go to the detriment of services toward less mobile factors ("race to the bottom"), and if it is accompanied by lower regulatory standards in fields with negative externalities, it may unleash "beggar thy neighbour" policies. In regulation, as argued by Woroch (1990) for United States telecommunications, "in their desire to attract new businesses and new citizens, regulators will compete with one another in terms of their policies. States could impose high access charges for interstate calls terminating in their state while showing favour to outgoing calls or intrastate traffic. This tendency could lead to beggar-thy-neighbour policies which can evolve into inefficient outcomes for all jurisdictions." There is no (at least, known to the author) systematic empirical evidence that explores these issues.

In vertical competition models (Treisman, 2007, ch. 6), different government layers taxing the same base lead to "overgrazing": i.e. too high taxation and lower output than under one tax (in a similar argument to double marginalization in Industrial Organization). Equivalently, two tiers providing complementary infrastructure investments may provide too little investment if they do not cooperate. However, cooperation is difficult to enforce in all relevant dimensions, and if it is achieved in one dimension but not in others, cheating may go in the noncooperative dimensions. Under lack of cooperation, increasing the revenues that accrue to the local powers may decrease appetite for expropriation, but increase the predatory instincts of the central layer.

Inman and Rubinfeld $(1997 \mathrm{a}, \mathrm{b})$ and Oates $(1999,2006)$ note that the conditions of the Tiebout model are not necessary for decentralization to be superior to centralization. In his Decentralization Theorem, Oates establishes that decentralization is a superior option provided that the benefits of accounting for heterogeneity outweigh the problems created by jurisdictional externalities and lack of scale. The optimal scale must take into account the costs of providing the service, the administrative costs of regulation and the communication costs between all the agents involved (see Treisman, 2007). Budzinski (2006) argues that these issues should be taken into account in the analysis of optimal jurisdiction in competition policy, and notes that appropriate geographic market definition is rarely used as an argument for allocating responsibilities.

The fixed administrative costs of regulation make it more likely that specialized regulatory functions will be developed when larger populations are involved (see Mulligan and Shleifer, 2005). It can be argued that to achieve policy differentiation and tailor the size of projects to total costs and benefits, political decentralization or federalism (democratically elected subcentral bodies taking decisions) is not needed, and local units of a central state can give absent communication problems to local projects. However, even in the absence of these problems, political decentralization may act as a commitment device for the robustness of policy differentiation, as argued by Inman (2008). Treisman (2006) finds that political federalism is positively correlated with the proportion of decentralized revenues or expenditures relative to those in the country as a whole.

Oates (2002) distinguishes three different settings in environmental regulation that call for different organizations in the vertical structure of government:

- Pure public goods, where the impact on any jurisdiction depends on the sum of local productions; examples being global warming, research. 
- Local public goods with no spillovers, where the impact on any jurisdiction depends on local production; the clearest example being garbage collection.

- Local public goods with spillovers, where public goods in one jurisdiction have some effect on neighbouring jurisdictions, the clearest example being environmental policies.

Pure public goods call for central responsibilities (although administrative and political feasibility as well as local information may make necessary some decentralized intervention, as in the European Trading System for pollution permits). Local public goods without significant spillovers call for decentralized intervention (although with capital mobility, if the "race to the bottom" is a reality, uniform standards, which may be better established with some sort of central intervention, may be necessary). In all these cases, the flexibility of laboratory federalism may become valuable due to global uncertainty ("the states as a laboratory of democracy").

Klevorick (1996) includes competition policy as an example of the sort of standards that some claim may be necessary to establish uniformly if the race to the bottom occurs. The author however claims that the arguments both for the existence of such race and, even if it exists, the necessity of uniform standards, are not overwhelmingly convincing. In regulated industries, there is a potential role for centralized, even for international powers in the setting of technical standards (see Gruber, 2005, on cellular telephony). A popular application of the "common standards" rationale is the argument that too many policies increase compliance costs and uncertainty, thwarting investment.

Even when common policies that internalize spillovers are preferable, local units may cooperate on policies that maximize their joint payoff, without the need for a central power. However, Coasian cooperation of sub-central jurisdictions (making central jurisdictions unnecessary) is possible only in very specific circumstances, as argued by Inman and Rubinfeld (1997a). Special districts in the sense of Frey and his co-authors can be interpreted as a version of Coasian cooperation, where specialised agencies of different (optimal) sizes to deal with individual services are proposed, as opposed to all-purpose institutions. ${ }^{11}$

The scale and specialization advantages of such institutions should be weighed against the problems related to the duplication of fixed costs, the interdependencies between different policies and the difficulties and costs of sustaining cooperation.

There is often the need to play complementary roles between the central and the local levels, for example the central level deciding on criteria or objectives and the local level being delegated the task of implementing the central guidelines and filling in the gaps when the central prescriptions leave some issues open. This has been called (vertical) cooperative federalism by some authors. ${ }^{12}$

\footnotetext{
${ }^{11}$ See Eichenberger and Frey (2006) and Casella and Frey (1992). Examples of special districts of different sizes include citizen communities in Swiss cantons to manage electricity distribution; metropolitan transport authorities; organizations in Spain to manage water use and irrigation; regional electricity transmission organizations combined with wholesale power markets such as PJM in the United States; or large international organizations to deal with specific issues such as NATO.

${ }^{12}$ See Stalon and Lock (1990) on energy and Nuechterlein and Weiser (2001) on telecommunications.
} 


\subsection{Second-generation Studies: Information, Commitment and Transaction Costs}

Starting in the late 80s, economic studies of federalism began to benefit from the development of the microeconomics of transaction and related costs, such as the costs imposed by asymmetric information or imperfections of the political process that surrounds policy-making. These issues are covered in this and the next sub-section.

Arguments related to information can go either way, depending on the type of information. Economies of scale in expertise favour central policy allocation, but proximity to local conditions coupled to communication costs favour decentralized policy-making. Exchange of information may be useful for the purposes of yardstick competition, e.g. across disjoint similar jurisdictions in charge of regulating electricity distribution. Or there may be huge product market externalities as in electricity transmission which justify centralized regulation but, even for transmission, the local level's informational (and political, for example, to overcome resistance to investments) input is useful. The central regulator transferring his better information (due to economies of scale in expertise) to the local regulators, or the other way around (due to proximity to local conditions) emerge a priori as sound cooperation strategies. There may be no externalities in the product market but there may still be informational externalities, as in the Laffont and Pouyet (2004) $)^{13}$ model. Location of expertise and good information are key issues in modern regulation. Aubert and Laffont (2002) argue that (p. 20): “...This type of thinking favours decentralization when local information is good and explains the trend toward local decision-making for managing natural resources, such as water and forests. On the other hand, for health and specific environmental issues, local information may be weaker than that of the central government, which has better access to international information." In the United States and the EU, the staff and other resources of state or member state commissions vary widely, and in general it is very doubtful whether they can perform analyses having the same technical quality as the federal agencies.

Analogies can and have been made between federalism, on one hand, and both the role of decentralization in the theory of the firm and the market (see Hayek, 1948) and trends in firm models in the real world, on the other hand. Bigness at the central level introduces planning costs in a similar way to the costs of managing large companies (see Mookherjee, 2006). However, decentralization may duplicate inefficiently some fixed costs of regulation. Better information at the local level may allow for better design of incentive mechanisms at this level (see Tommasi and Weischelbaum, 2007). Oates (1999, p. 1137) argues that "the vertical structure of government may have important implications for the way in which the public sector functions and its impact on the operation of a system of markets." Decentralization can also be a way to delegate and avoid overload, as was argued, for example, in the reform of European merger policy. Caillaud et al. (1996) present an interesting model where there is delegation, but the central power can still influence the bargaining relationship between better informed local regulators and firms by using transfers.

The analogy with the theory of the firm is also used by the proponents (Weingast and his coauthors) of "market-preserving federalism": a commitment to not concentrate authority and

\footnotetext{
${ }^{13}$ This paper presents a brief, but useful, review of contract theory models related to decentralization issues. Baron (1985) presents one such model where a federal environmental agency may or may not cooperate with a state product regulation commission. The output is produced in a particular state but production involves pollutants that affect other states. Efficiency can only be achieved by cooperation, but this may be inhibited by distributional considerations.
} 
information may play a similar role as committing to not fall into a ratchet effect in agency theory. Proponents of "market-preserving federalism"14 argue that under some conditions, a decentralized system preserves the growth of a market economy. These conditions typically include decentralized "primary" regulatory responsibility; a single market for the whole federation; centralized monetary policy and an absence of central bail-outs. However, Rodden and Rose-Ackerman (1997) argue that the conditions stated by Weingast and his co-authors, which would certainly make federalism preserve markets, are very unlikely to be self-enforcing or even mutually compatible. For example, it is difficult to envisage that decentralization could avoid exacerbating inequalities, thereby compromising the political sustainability of the federallocal compact. Similarly, it is difficult to imagine that a central state without relevant economic policy levers would be able to police a common market and avoid local protectionism.

In the absence of sufficient regulatory commitment, more information is not always beneficial in dynamic settings. Qian and Weingast (1997) argue that reducing the information available to central powers reduces the temptation they have to expropriate investments. But Spector (2007) suggests that in some cases (viz. indirect taxation in the EU) the local (national) powers may prefer to delegate strategically to central powers to avoid political criticism. For example, in the relationship between decentralization and macroeconomic management or reform, federalist structures create veto points that provide commitment, but also stall welfare-enhancing reforms (Rodden and Wibels, 2002). The order of reforms should then be: first reform at the national level, then decentralize to provide commitment (Treisman, 2000).

Troesken (1996), in a detailed account of the history of the gas industry regulation in the city of Chicago (with some references also to the history of other United States cities), argues that the move from local franchises to state regulation, which took place in the United States under lobbying by regulated firms in the first decades of the $20^{\text {th }}$ century, was rooted in the inability of local politicians to commit to not expropriate sunk investments. Local franchises evolved into a system of politicized and arbitrary local regulation after technological change triggered by the use of water gas caused the entry of new firms in the gas industry and a subsequent process of deregulated consolidation. State institutions would be more able to commit ${ }^{15}$ than local institutions because the ability of consumers to organize and exert political pressure ex post at the state level is relatively lower.

Troesken (1996, p. 89) reports that the vice-president of the Pacific Gas and Electric Company argued that under municipal regulation, corporations were "at the mercy of as pitiless a pack of howling destroyers, as would the lonely traveller on the Siberian steppes be against the gaunt and hungry wolves." The company vice-president advocated state regulation, in part, because state commissions would set rates in "calm deliberation and not in political heat."16

\footnotetext{
${ }^{14}$ Rodden and Rose-Ackerman (1997) and Rubinfeld (1997) place this theory in the framework of the New Institutional Economics.

15 The higher profits of firms under state regulation than firms without state regulation found by Stigler and Friedland (1962) would then be evidence of state regulation yielding higher profits than local regulation, but not higher profits than deregulation.

${ }^{16}$ Neufeld (2008) shows that for United States electricity regulation, quasi-rents due to specific investments were a more important determinant than monopoly rents in the decision to move from local to state regulation. Nonnenmacher (2001), however, argues that in the diffusion of the state regulation of the telegraph industry, a cycle characterized by promotion followed by regulation was more important than quasi-rent considerations.
} 


\subsection{Second Generation Studies: Capture and Accountability}

Seabright (1996) argues that incomplete contracts considerations matter in the jurisdictional allocation debate because if everything could be specified in a contract, decentralization would be irrelevant; it is because contracts are incomplete that accountability matters. Then using an incomplete contracting framework, he argues that central powers are less accountable because they do not face electoral pressures for decisions in one particular sub-central unit. Bardhan and Mookherjee (1999) explain, however, that the effectiveness of capture at each level depends on specific political conditions that vary across jurisdictions. Marshaw and Rose-Ackerman (1984) argue that the support of producers to centralization or decentralization depends on the particular industry structures and on the specific results they may obtain. Rodden and Wibels (2002, footnote 12) argue that a key problem with informational arguments in favour of decentralization is that information-constrained voters might be more inclined to monitor the central government than local governments ${ }^{17}$ and that shared or overlapping authority might make accountability more difficult. Shleifer and Vishny (1993) relate corruption incentives to the vertical structure of government. They argue that when central governments have a strong grip on the lower layers of government, corruption levels are lower because a double marginalization problem is avoided. Local corruption levels can be reduced, however, when political competition is strong.

Spector (2007) and Woroch (1990) discuss the possibility that decentralized levels have shorter time horizons. This may be related to citizen mobility or political volatility, which may vary across regions. For example, it can be argued that the EU Commission (EC) is less immune to political volatility than the United States Federal government because the main political parties are by design represented in the EC.

Bardhan and Mookherjee (2006) compare two types of non-benevolence (bribes in centralization, electoral capture in decentralization) with a variety of available instruments (user fees or taxation) in the case of decentralization. Policymakers decide on the levels of service delivery for a segment where the only relevant costs are constant marginal costs (the fixed costs correspond to an exogenous upstream producer from whom deliverers buy). Results for each case are compared to a first and second best (with deadweight loss of taxation) in terms of efficiency, welfare (efficiency plus equity between two demand types for each region) and level of service delivery. User fee finance dominates decentralization with local taxation because voluntariness of local fee financing constrains the extent to which elites may be overprovided at the expense of non-elites. Decentralization with central grants may dominate centralization and user fees in specific cases.

Inman and Rubinfeld (1997b) provide an extensive and insightful review of the exemption from anti-trust legislation that the states often enjoy in the United States. This exemption goes back to the United States Supreme Court Parker case, where a policy decision by the state of California granted a cartel to producers of agricultural products consumed overwhelmingly outside of the state of California. Although Inman and Rubinfeld criticize this particular case for not taking spillovers into account, they claim that in many cases, in the absence of such spillovers, states' policies should be exempted from antitrust legislation if they satisfy the condition that the policy is enacted under

\footnotetext{
${ }^{17}$ If we take election turnout as a proxy for the amount of information that voters possess, in Europe this turnout is highest for national elections, lower for regional elections and lowest for European Parliament elections (other European offices, such as the European Commission and the European Council, are not directly elected). This suggests that whereas the national policies are better monitored than regional policies, European policies are the worst monitored.
} 
conditions of political participation. The impressive work of these authors is, however, vulnerable to two criticisms: first, it focuses on a model of "bright lines" regulation, whereas many regulatory decisions are made by jurisdictions that share regulatory powers; second, the more recent literature (see, for example, Bardhan and Mookherjee, 1999, and Treisman, 2007) shows that it is not clear that more participation goes hand in hand with decentralized policies. Nevertheless, this work shows that political participation, together with economic efficiency, is a key element in the role of decentralized powers. A role for the federal level certainly persists in the case of pure (national) public goods or positive spillovers if states' cooperation is precluded. In the case of negative externalities, the situation is more complicated because universal agenda-setting rules at the federal legislative may imply that a similar pattern of decisions is adopted at the federal and decentralized levels. In this case, federal intervention should be restricted to setting maximum levels of the externality. To improve the terms of the trade-off between political participation and economic efficiency, a participation test should take into account the participation of states affected by spillovers. The authors argue that although almost all policies have jurisdictional externalities, these should be taken into account in the architecture of government only when they are significant, and that standards of significance similar to those used for market definition in anti-trust policy should be used (i.e. an impact of 5\% difference). Interestingly, throughout their article, the authors argue that participation is best guaranteed by the legislative power ${ }^{18}$ (through both well-articulated policies and ex post mechanisms for monitoring), and not by regulatory agencies. ${ }^{19}$ More generally, this study shows that it is valuable to go beyond the theories that only consider the demand side of policy-making (like the Tiebout model or, in part, the market preserving federalism theory) to open the black box of the supply side, and analyze the whole range of incentives and constraints that drive political and regulatory decisions.

\section{Table 1}

Summary of Arguments

\begin{tabular}{|c|c|c|c|}
\hline & $\begin{array}{c}\text { Favours Central } \\
\text { Regulation }\end{array}$ & Favours Local Regulation & Ambiguous \\
\hline First Generation & $\begin{array}{l}\text {-Externalities and scale. } \\
\text {-Coordination. } \\
\text {-Race to the bottom. } \\
\text {-Beggar thy neighbour. }\end{array}$ & $\begin{array}{l}\text {-Laboratory federalism. } \\
\text {-Tailoring. } \\
\text {-Regulatory Competition. }\end{array}$ & -Market definition. \\
\hline Second Generation & $\begin{array}{l}\text {-Quasi-rents } \\
\text { (overgrazing). } \\
\text {-Compliance costs. } \\
\text {-Discount factor. } \\
\text {-Regulatory capacity. }\end{array}$ & $\begin{array}{l}\text {-Market-preserving } \\
\text { federalism. } \\
\text {-Political participation. }\end{array}$ & $\begin{array}{l}\text {-Contractual } \\
\text { issues. } \\
\text {-Accountability. } \\
\text {-Veto points. } \\
\text {-Capture. } \\
\text {-Commitment. }\end{array}$ \\
\hline
\end{tabular}

18 In some occasions, state legislative input and stakeholders' participation has not been enough to prevent regulatory failures. In the restructuring of electricity in California, the chair of the committee that drafted the legislation "rather than encouraging the usual behind-the-scenes negotiations of competing bills put forth by different interest groups, he held marathon public sessions in which all stakeholders had to work on a single bill together, often into the wee hours of the morning" (Blumstein et al., 2002). Inman and Rubinfeld (1997b) argue that it is precisely the complexity of regulatory issues (such as arguably the optimal restructuring policy for electricity) that makes political participation more important, and that this is better achieved at decentralized levels.

19 For an opposite view, Moore (2002) argues that complexity and a higher discount rate would have made regulatory agencies better qualified than the legislator in designing electricity deregulation in California. 
Table 1 summarizes some of the arguments used in the economics of federalism debate. The arguments are organized in the table according to three dimensions. The three columns (first dimension) include those arguments that favour central or local regulation, or that are ambiguous. The two rows (second dimension) distinguish between those arguments that were made before the 1980s and those that were made later, after the eruption into economic theory of contract theory and political economy models. A third dimension distinguishes those arguments related with markets' structural conditions (in italics) from those that are orthogonal to issues such as technology or externalities.

As can be seen, modern arguments based on contract theory or political economy have not clarified what should the decision be, although they have given greater sophistication to the analysis of jurisdictional allocation,. One could say that we are still confused, but at a higher level.

First-generation decentralisation arguments provided clearer guidance, and were more closely related to the structural conditions of markets. This matters in an analysis of EU policies because the subsidiarity principle of the Maastricht treaty places the burden of proof on central, federal levels, and accordingly, those arguments that provide ambiguous conclusions should be of little use to support the role of the federal level.

\section{European Regulatory Reform and Liberalization}

The reform of network industries in Europe tries to liberalize and, at the same time, fix the right location of policy in the vertical structure of government. Industry reform changes the boundaries between markets and regulation, and also the boundaries between regulatory jurisdictions. EU regulatory frameworks set out objectives and rules for national regulators and governments, whilst granting them flexibility in certain areas to apply the rules in the light of national conditions. This section explores how this is done in the telecommunications and electricity industries.

To make liberalization possible, a number of policies that were buried under decisions concerning the vertically integrated public national monopoly are now part of an unbundled policy vector, and the arguments of this policy vector are not controlled by a single body. The need for vertical and horizontal cooperation then arises, but cooperation may be inhibited by distributional concerns (Baron, 1985). For example, industrial or environmental policies that interact with broadband or electricity markets are not always taken at the same jurisdictional level as regulatory decisions. With liberalization, all government levels may intervene, and there is more institutional complexity.

For example, different authorities may control behavioural and structural regulation (which are clearly interdependent), as illustrated in Gilbert and Riordan (1995) or Perry (1984). According to Joskow (2009), the FERC in the United States has been constrained to use behavioral instruments to control market power in wholesale markets when it would have been optimal to use structural instruments, for which it does not have jurisdiction. The starting point of deregulation is characterized by geographical fragmentation and typically member states in the EU, like the states in the United States, are free riders in the path to competition: they would benefit from more integrated and competitive markets in the long run, but do not want to lose the lever they have on territorial incumbents to both maintain or promote national champions and use regulated cash flow to promote a number of local objectives. 


\subsection{Electricity}

After the pioneering experiences of some member and neighbour states such as the United Kingdom and Norway in the $1980 \mathrm{~s},{ }^{20}$ the EU began an effort of gradual electricity liberalization starting with the first Directive in 1996 (Green, 2007). The first Directive was a compromise between countries that had started liberalization and those that contemplated it as a very remote possibility. It was also a compromise between countries with very different market structures, from countries with vertically integrated publicly-owned national companies to countries with public or private firms of a local or regional nature. It included an objective of accounting separation between potentially competitive and monopolistic segments; an objective of freedom of choice for large consumers; and an objective of increasing autonomy of transmission networks. However, it still accepted negotiated instead of regulated third-party access to networks.

The second Directive in 2002 took additional steps towards reform, such as the requirement that member states should create independent "national regulatory authorities." However, independence was defined as independence from the incumbent operator rather than from the government, although almost all EU countries have, in practice, established a regulator that is relatively independent of government, at least for transmission pricing and wholesale market arrangements. The Directive also put in place a calendar for the freedom of choice of retail supplier by all consumers, including households.

In 2007, the Commission publicized the results of a competition investigation that contained many criticisms of the state of competition in the electricity sector. ${ }^{21}$ In particular, three interrelated problems were mentioned: excessive horizontal concentration in generation, excessive vertical integration between generation and transmission and insufficient interconnection among national grids. As a result of this investigation, a third package of directives was launched. In this package, the Commission proposed to stress vertical separation and promote the interconnections between countries. ${ }^{22}$ It includes the creation of mandatory independent system operators. Although the option of full ownership separation of transmission had been contemplated, this was unacceptable to countries with vertically integrated operators (primarily France and Germany).

Many experts believe that ownership separation between transmission and generation, combined with integration between the firm that owns the high voltage grid and the system operator (as in Spain or the United Kingdom) is the ideal solution. However, in practice perhaps progress should not be excluded towards either a European-level system operator or at least regional system operators that respect national ownership of grids.

The new package strengthens the authority of national independent regulators, which are now defined as independent from government as well as from the incumbent. And it also reinforces the current coordination body of national regulators, rejecting other possibilities such as delegating European regulation on national bodies or creating a separate European regulator. In

\footnotetext{
${ }^{20}$ Interestingly, one of the most interesting and successful experiences of market integration in Europe has been the NordPool, a wholesale electricity market organization that encompasses several Scandinavian countries, which originated in Norway, a country that does not belong to the EU (see Wagensteen, 2007). The NordPool, as the PJM and other Regional Transmission Organizations in the United States, are examples of the special districts mentioned by Frey and his co-authors (see Section 2 above).

${ }^{21}$ See European Commission (2007).

22 The $3^{\text {rd }}$ Package was enacted in April 2009. See http://www.europarl.europa.eu/news/expert/infopress_page/05154057-111-04-17-909-20090421IPR54056-21-04-2009-2009-true/default_en.htm
} 
particular, it creates an Agency for the Cooperation of Energy Regulators, which comprises an Administrative Board, a Board of Regulators, a Director, and a Board of Appeal. This Agency will have a mainly advisory role, but it will also have decision powers on transmission issues that affect at least two member states.

Until the second directive, European liberalizing efforts in electricity focused on the retail level. This contrasts with United States liberalization, where the federal level focused on the wholesale level, and left discretion to the states on the decision to open retail to competition or otherwise. In spite of increasing efforts to interconnect, Europe is still a collection of separate markets (seven in total, according to Haas et al., 2006).

Traditional jurisdictional administrations seem ill-suited to manage optimally-sized transmission network and wholesale generation markets. In these fields, regulatory harmonization facilitates market integration, so that, for example, efforts to harmonize the terms of access to interconnections managed by national authorities usually precede efforts to physically increase the capacity of interconnections. But these interconnections are today clearly insufficient compared to what would be the optimal size of the wholesale market, implying that Europe is today more a collection of isolated regional electricity markets than a common internal market.

Under the standard recipe of competition where possible and regulation where necessary, the question emerges of who should regulate the differently-sized segments of the electricity industry. The monopolistic segments of the industry (distribution and transmission) have different optimal sizes (see Table 2).

\section{Table 2}

Interaction between competition potential and geographic scope in electricity

\begin{tabular}{|l|l|l|}
\hline & Competitive & Monopolistic \\
\hline Local & Retail & Distribution \\
\hline $\begin{array}{l}\text { Regional } \\
\text { (international, continental) }\end{array}$ & Generation & Transmission \\
\hline
\end{tabular}

Structural market conditions then suggest that the regulation of the transmission monopoly should be supranational and the regulation of distribution should be local, with supranational competition policy controlling market power in generation and national competition policy controlling market power at the retail level.

Gual (2007) argues that, under the current conditions, there are fewer limits to host country rules in electricity than in telecoms. This causes substantial differences in terms of the regulatory conditions faced by domestic competitors, while, at the same time, the Commission is trying to forge a very concrete path towards national deregulation, in spite of different fuel sources and national traditions. There seems to be an inconsistency between the efforts devoted to opening up competitive segments and the fact that the advantages of incumbents in some markets are left almost untouched. Gual (2007) concludes that compared to telecoms, banking and more conventional product and service competitive markets, the EU integration strategy has been less effective in electricity. 


\subsection{Telecommunications}

For decades, the telecommunications markets in Europe were based on publicly-owned verticallyintegrated national monopolies. The telecommunications sector was not a concern for the European authorities until the 1980s, when a Green Paper expressed concern over the lack of competition in these markets and the potential role that a better functioning telecommunications sector could play in enhancing the region's economic dynamism. The European Commission led the liberalization wave of the nineties, which was accompanied by (to different degrees) privatization of national incumbents. ${ }^{23}$ With a similar timing as in electricity, the first two packages of directives tried to progressively introduce competition in national markets and, at the same time, increase the role of the European Commission in overseeing these markets in a piecemeal way (Seabright, 1998). The first Telecommunications package set a timetable for the liberalization of national markets, including provisions for open access and the removal of cross-subsidies. The second package included a detailed procedure for the analysis of each of the 18 markets identified in the sector. According to this procedure, the national regulatory authorities had to analyze these markets ${ }^{24}$ and determine (with the agreement of the European Commission) whether there was significant market power in each of these markets. If it was determined that market power was significant, the national authority had discretion to introduce ex ante regulatory remedies.

The first two packages combined implied more harmonization (clearly useful for technical standards) than market integration. Gual and Jodar (2007) provide a useful summary of the results achieved under the current system.

Partial harmonization was promoted under the argument that regulatory inconsistencies are a major entry barrier for companies that want to operate in several countries. A reasonable framework was set for vertical cooperation between EU authorities and national authorities, with yardstick regulatory competition (benchmark reports), balancing harmonization to reduce entry barriers (and to prevent uneven competition) with knowledge of local conditions: what is called "host country rule within limits" (Gual, 2007; according to this author, however, "results have been fairly limited so far"). Many of the harmonization rules have gone in the direction of opening the local loop, to ensure that national rules did not protect local incumbents. The Commission has also been very active on mobile telephony, for example, ensuring that roaming charges for consumers that were using their handsets in foreign EU countries were not too high. ${ }^{25}$

The third package ${ }^{26}$ currently under discussion includes the following new features:

- Fewer markets are presumed to need ex ante regulation (with focus on wholesale markets), but an EC role is introduced in the determination of remedies when market analysis determines the existence of significant market power.

- Creation of a European Market Authority. Under the current proposal, this will be a body of NRAs called precisely Body of European Regulators for Electronic Communications

\footnotetext{
${ }^{23}$ Privatization has never been required by EU directives. Indeed, the Treaty of Rome would forbid any such EU legislative obligation.

${ }^{24}$ National authorities must also determine the geographic market definition, but routinely decide in almost all cases where markets are national.

${ }^{25}$ The Commission has also been active in the harmonization of technical standards for batteries, and emergency telephone numbers.

${ }^{26}$ See http://ec.europa.eu/information_society/policy/ecomm/tomorrow/reform/index_en.htm
} 
(BEREC). It will have an advisory role, focused on transnational markets, harmonisation and cross-border disputes.

- Focus on spectrum liberalization and other potential European-wide service markets.

However, even if the package is finally approved under the current version, the final result will be far from achieving the market integration level of the United States where, after a process of industry consolidation, a limited number of firms compete nationally in television, fixed and mobile telephony and broadband Internet access.

According to Seabright (1998), it is not straightforward to separate those regulatory issues that involve significant cross-border externalities because of economies of scope between types of service (e.g. local and long-distance calls). The result is that the EU assumes powers piecemeal, as member states are willing to concede them, and on the basis of a generalized dissatisfaction with progress towards some (usually vaguely specified) notion of an ideal single market rather than a coherent application of the rules of subsidiarity.

The specific technological requirements of telecommunications, plus the possibility of significant network externalities, have led some to argue that centralization at the EU level is the only way to regulate this sector reasonably efficiently. Whatever the truth of this argument, similar piecemeal processes in other sectors in the past have sometimes led to assignments of power to the EU that look hard to justify according to any such principles (such as in the Common Agricultural Policy).

The argument that centralization is the only way has been made by Hoffinger (2003), Hahn et al. (2003), Lehr and Kiessling (1999), and Sun and Pelkmans (1995). Federal regulation should focus on those aspects that amount to clear externalities, for example:

a) "Beggar thy neighbour" policies in wholesale roaming termination charges (but keeping a balance that avoids precluding European-wide commercial initiatives by companies to reduce retail roaming rates).

b) Any policies that cause what Sun and Pelkmans (1995) call the "frontier effect," namely, the fact that equally costly products or services are more expensive when they cross a jurisdictional border than when they take place inside the borders of a member state; more generally, legal barriers to entry should be eliminated, and only structural barriers to entry should prevail in the long run, which implies helping to integrate those markets that are only stopped by separate legal jurisdictions.

c) Protectionist terms of access or licensing policies that entrench the position of national incumbents or are equivalent to state aid in promoting the international competitiveness of national incumbents. Credible entrants are typically foreign incumbents and the temptation to embark in subtle ways on promoting national telecom companies are often hard to stop under conventional EU checks against 'state aid.'

It is difficult to argue that the central policy should be the only game in town because of generic network externalities, because, at least for voice telephony markets, universal service has been achieved. In those markets where the full population is not covered, such as broadband, it is hard to argue that network externalities in the sense of extending the service will be better served by European agencies than by well-targeted local initiatives. 
Even in a competitive telecommunications sector with more integrated markets, the scope for national or regional/local policies will not disappear. First, local powers may help alleviate the collective action problem of managing the rights of way and physical infrastructures common to competing networks. Second, they may participate in efforts to achieve regulatory geographic differentiation. Finally, some territories may undertake experimentation with regulatory or competitive strategies that have not achieved a general consensus, such as functional vertical separation or others. All of these suggest a continuing role for regional and local policies, even if overall EU frameworks are likely to be set centrally.

The product markets that national and European authorities must in practice jointly analyze should undergo a more sophisticated analysis of geographic market definition, which should take into account not only the current legal conditions, but also the optimal legal conditions that should leave in place only those barriers that are due to technology and consumer preferences (in a similar way to the literature on optimal currency areas in monetary policy, but applied to all product markets, because different product markets may have different optimal geographic sizes).

Table 3 summarizes a characterization of telecom markets that is analogous to the characterization of Table 2 for electricity. In this case, the division between local and regional is less precise because of changing and converging technologies. The main difference that emerges is that in telecommunications, those segments that are typically supranational are competitive in nature, and so should be the object of less intrusive and ex ante regulation. It is somehow paradoxical that as liberalization progresses, the supranational regulatory authorities take more responsibility in the ex ante regulation of less competitive segments that are usually structurally local, and that also are progressively being opened up to competition. Besides the possible inconsistencies from the point of view of the economics of federalism, the ex ante regulatory rules to enforce local regulation (which contrast with an orientation towards facilities-based competition in the United States), or Commission interventions on mobile roaming and other cross-border charges, show that the particular features of the harmonisation being imposed is perhaps enforcing a 'managed competition' outcome with possible adverse consequences for longer run innovation and competition.

\section{Table 3}

Interaction between competition potential and geographic scope in telecommunications

\begin{tabular}{|l|l|l|}
\hline & Competitive & Monopolistic \\
\hline Local & $\begin{array}{l}\text { Intermodal } \\
\text { communications }\end{array}$ & Fixed Local Access \\
\hline $\begin{array}{l}\text { Regional } \\
\text { (international, continental) }\end{array}$ & $\begin{array}{l}\text { Long-distance } \\
\text { communications }\end{array}$ & \\
\hline
\end{tabular}

\section{Conclusions and Implications for EU Infrastructure Industry Regulation}

Some scholars ${ }^{27}$ argue that liberalization requires a centralization of regulatory authority at the central, federal level, to overcome the resistance of local regulators who put incumbent or other

\footnotetext{
27 Joskow (2009), Lehr and Kiessling (1999), Sun and Pelkmans (1995), Hahn et al. (2003), Hoffinger (2003).
} 
interests above the goal of market efficiency. This would be compatible with a withdrawal of federal regulation at a later stage when the progress of liberalization is deemed sufficient (one wonders why these scholars have confidence in the disappearance of the federal regulator but not in the disappearance of the national/local regulator). However, the control of rights of way and political sensitivity at the positive level make national or regional/local participation to some extent unavoidable. Different jurisdictions will control different parts of the multidimensional policy vector that affects liberalizing sectors. Optimal modularity (fine-tuned unbundling of firms and regulatory responsibilities) decisions are often difficult to make or enforce in complementary (electricity) or rapidly changing (telecommunications) markets. This makes vertical cooperation a necessary attribute of a sound regulatory system (as suggested by Nuechterlein and Weiser, 2007), and that type of cooperation has been a key feature of EU telecommunications in the recent past.

Harmonization has made more progress in telecommunications than in electricity, although the potentially competitive nature of all telecommunications markets and the need for flexibility due to rapidly changing technology make harmonization in telecoms less necessary than in electricity. In the latter industry, horizontal cooperation between member states (as in the development of the NordPool or other regional markets) has often replaced or preceded the slow progress towards the necessary physical interconnection and federal regulation of markets that have an optimal geographic scope beyond national borders.

On the basis of our literature review on the economics of federalism, it seems that a decision to allocate all relevant European Union regulatory authority at the highest level may be premature. Member State and, in some cases, lower level participation is still desirable at a normative level.

This paper suggests that the case for national and sub-national regulation in the EU is strongest when:

a) The policy intervention is about a good or market that is geographically local in nature, with few or non-significant spillovers (e.g. local access), or when sound regulatory decision-making requires considerable knowledge of local conditions, (e.g. on policies for areas not served by rural broadband).

b) Regulatory controversies are so numerous or time-consuming as to be beyond the resources at the EU Federal level.

c) Member state financial participation would advance a costly federal objective. On this issue, the courts and the telecommunications Universal Service Joint Board in the United States have recognized the advantages of a state-federal partnership in universal service.

d) State or regional/local enforcement of existing federal or state standards produces better results for retail or wholesale consumers. For instance, lower government levels are often the first point of contact for consumer complaints, and typically offer quicker and more effective responses to such complaints.

e) There is a need to respond to new problems where a single federal policy would be premature. For example, early state actions regarding telephone number pooling guided subsequent FCC policies in the United States.

Decentralization and the creation of a common internal market are clearly compatible. The largest and most successful internal market in historical terms (the United States) is substantially 
decentralized. The work of Tiebout and Weingast reviewed in Section 2 suggests (at least theoretically) that the federal level should focus on policing well functioning and integrated markets, but that it should delegate (in a framework of vertical cooperation when necessary) most residual behavioral regulation to lower level governments. Applying this perspective, the EU should focus its own scarce central resources and political capital in an increased effort towards market integration, especially in the fields of electricity transmission and radio-electric spectrum.

Although compliance costs and the entrenchment of national incumbents are important arguments to take into account in reaching some effective level of harmonization, the subsidiarity principle of the Maastricht Treaty suggest that unless there is a clear role of externalities and economies of scale, regulation should be performed at the lowest levels. Further, these externalities and economies of scale should not be taken as given for all time, but should be restricted to those that result from structural market conditions. Hence, the focus for EU policy in this area should be on removing all legal barriers that currently prevent the existence of markets with the optimal geographic scope.

The EU 'third packages' in electricity and telecoms do not exhaust the debate on regulatory federalism. The debate on regulatory jurisdiction has been very lively since the creation of federal regulatory authorities in telecoms and electricity in the United States in the 1920s. The ongoing debate in Europe should consider more seriously some forms of cooperation that are well supported by experience as shown in the relevant literature. This includes:

- Regulatory specialization: Taking into account the fixed costs of regulation (Mulligan and Shleifer, 2005), some national regulators could, for instance, specialize in spectrum issues and others in electricity interconnections. Similarly, other authorities could delegate at least the analysis prior to decisions to these more specialized bodies.

- Temporary regulatory experimentation: Delegation to regional and local levels could, for example, be very useful in developing next-generation networks in broadband, where even the best experts often disagree on the optimal balance between facilities-based and access-based competition.

- Cooperative solutions (or clarification of its illegitimacy in some cases) of the "other objectives" that often pervade local or national decision-making: Some degree of delegation within a central perspective could be helpful in resolving the sometimes major policy difficulties that arise in, for example, security of supply in energy, attitudes to 'national champion companies,' universal service definitions, etc.

- Local input in geographic differentiation or in solving collective action problems concerning the joint use of physical infrastructures: for example, also in the deployment of next-generation broadband networks.

The second packages of both telecom and electricity reform in the EU included a clear reinforcement of the role and responsibilities of independent national regulatory authorities. The third European packages include the creation of separate European-level authorities (based on the national regulators) and a consensus seems to be emerging that these authorities will amount to the institutionalization of a cooperative body of independent national regulatory authorities. The new body will have an advisory role in telecommunications but will have some decision powers in energy. Whereas the horizontal cooperation between national regulators is necessary, the marginal benefit of an independent body beyond the regulatory role of the European Commission (a multi-partisan and multi-country executive body) is questionable. This 
is specially so in energy if the new agency is more independent than the constituent national regulatory agencies: the agency may be coordinating the wrong agents (if the main national decision-making authorities are the national executives and not the regulatory agencies), and the members of the EU Agency may spend time fighting for the national powers that their national authorities resist granting them, in a sort of corporatist club. If the largest efficiency gains must come from market integration and the resistance to this integration is mainly political, perhaps the Commission should focus on trying to overcome such resistance politically - as it has done to overcome the national resistance to competition policy through the political leadership of Commissioners Brittan, Monti and Kroes, for example. Bernstein (1955) suggested a long time ago that one of the disadvantages of independent regulators is their built-in isolation from the political process, which incapacitates them from leading necessary but resisted reforms.

Different societies (and nation states) may quite legitimately have different preferences concerning the trade-off between static efficiency and dynamic efficiency - issues that are often at the core of some regulatory decisions (e.g. opening networks to entrants on favourable terms). To see what might be achieved with a system of federal regulation that respects these differences and, at the same time, promotes collective objectives, consider, for instance, what has been achieved in policies to fight climate change. A central framework for cap-and-trade emissions policy has led to different national regimes and priorities. Although these are controversial initiatives and they are work in progress, they are leading the way for other regions of the world, and provide a reasonable framework for collective learning. 


\section{References}

Armstrong, M., Sappington, D. (2006), “Regulation, Competition and Liberalization," Journal of Economic Literature, 44, pp. 325-366.

Aubert, C., Laffont, J.J. (2002), "Designing Infrastructure Regulation in Developing Countries,” in Beato and Laffont (eds.), "Competition Policy in Regulated Industries," Approaches for Emerging Economies, Interamerican Development Bank.

Bardhan, P., Mokherjee, D. (1999), "Relative Capture of Local and Central Governments," CIDER Working Paper C99-109; also in Eskeland, G., Devarajan, S., and Zou, H.F. (eds.), "Fiscal Decentralization: Promises and Pitfalls," World Bank. A shorter version of the paper has been published in American Economic Review, May 2000.

Bardhan, P., Mookherjee, D. (2006), "Decentralisation and Accountability in Infrastructure Delivery in Developing Countries," Economic Journal.

Baron, D.P. (1985), “Non-cooperative Regulation of a Non-localized Externality," Rand Journal of Economics, 16(4), pp. 553-568.

Beato, P., Laffont, J.J. (2002), Editors' Introduction, in Beato and Laffont (eds.), "Competition Policy in Regulated Industries," Approaches for Emerging Economies, Interamerican Development Bank.

Bernstein, M.H. (1955), "Regulating Business by Independent Commission," Princeton University Press.

Blumstein, C., Friedman, Lee S. and Green, R. (2002), "The History of Electricity Restructuring in California," Journal of Industry, Competition and Trade, 2(1/2), pp. 9-38.

Brennan, T. (2003), "State and Federal Roles in Facilitating Electricity Competition: Legal and Economic Perspectives,” Resources for the Future, Discussion Paper 03-24.

Budzinski, 0. (2006), "International Competition, Economics of Federalism, and Competence Allocation Rules,” mimeo.

Caillaud, B., Jullien, B. and Picard, P. (1996), "National vs. European Incentive Policies: Bargaining, Information and Coordination,” European Economic Review, 40, pp. 91-111.

Casella, A., Frey, B. (1992), "Federalism and Clubs: Towards an Economic Theory of Overlapping Political Jurisdictions," European Economic Review, 36, pp. 639-646.

Dixit, A. (1996), “Economic Policy. A Transaction Costs Analysis of Politics,” The MIT Press.

Easterbrook, F.H. (1983), "Antitrust and the Economics of Federalism," Journal of Law and Economics, 26(1), pp. 23-50.

Eichenberger, R., Frey, B. (2006), "Functional, overlapping and competing jurisdictions (FOCJ): a complement and alternative to today's federalism," in Ahmad, Brosio (eds.), "Handbook of Fiscal Federalism.”

European Commission (2007), “DG Competition Report on Energy Sector Inquiry,” Brussels. 
Gilbert, R.J., Riordan, M.H. (1995), "Regulating Complementary Products: a Comparative Institutional Analysis," Rand Journal of Economics, 26(2), pp. 243-256.

Green, R. (2007), "EU Regulation and Competition Policy among the Energy Utilities," IESE Conference on the $50^{\text {th }}$ anniversary of the Treaty of Rome.

Gruber, H. (2005), “The Economics of Mobile Telecommunications,” Cambridge University Press.

Gual, J. (2007), “Integrating Regulated Network Markets in Europe," “la Caixa” Economic Papers, 05.

Gual, J., Jodar, S. (2007), "European Telecoms Regulation: Past Performance and Prospects," IESE Conference on the 50th Anniversary of the Treaty of Rome.

Hahn, R.W., Layne-Farrar, A., and Passell, P. (2003), "Federalism and Regulation. What Sorts of Regulation Are Best Handled on the Federal Level," Regulation, Winter, pp. 46-50.

Haas, R., Glachant, J.M., Auer, H.; Keseric, N. and Pérez, Y. (2006), "Competition in the Continental European Electricity Market: Despair or Work in Progress," in Shioshansi, F.P., W. Pfaffenberger (eds.), "Electricity Market Reform. An International Perspective," Elsevier.

Hausman, W.J., Neufeld, J.L. (1991), "Public Policy and the Structure of the Electric Power Industry: Lessons from the Past, in Regulatory Responses to Continuously Changing Industry Structures," Proceedings of the Institute of Public Utilities Twenty-Third Annual Conference.

Hausman, W.J., Neufeld, J.L. (1999), "Falling Water: The Origins of Direct Federal Participation in the US Electric Utility Industry, 1902-1933," Annals of Public and Cooperative Economics, 70(1), pp. 49-74.

Hausman, W.J., Neufeld, J.L. (2004), "The Economics of Electricity Networks and the Evolution of the U.S. Electric Utility Industry, 1882-1935," Business and Economic History On-Line, Vol. 2.

Hayek, F.A. (1948), “The Economic Conditions of Interstate Federalism," in "Individualism and Economic Order.”

Hoffinger, R.R. (2003), "Cooperative Federalism gone wrong: The Implementation of the Telecommunications Act of 1996," Journal of Telecommunications and High Technology Law, 2, pp. 375-397.

Humplick, F., Estache, A. (1995), “Does Decentralization Improve Infrastructure Performance?,” in Estache, A. (ed.), "Decentralizing Infrastructure. Advantages and Limitations," World Bank Discussion Paper 290.

Inman, R.P. (2008), "Federalism's Values and the Value of Federalism," CESifo Economic Studies, 53(4), pp. 522-560.

Inman, R.P., Rubinfeld, D.L. (1997a), "Rethinking Federalism," Journal of Economic Perspectives, 11, pp. 43-64.

Inman, R.P., Rubinfeld, D.L. (1997b), "Making Sense of the Antitrust State-Action Doctrine: Balancing Political Participation and Economic Efficiency in Regulatory Federalism," Texas Law Review, 75(6), pp. 1203-1299. 
Joskow, P. (2009), "Foreword: US vs. EU Electricity Reforms Achievement," in Glachant, J.M. and Lévêque, F. (eds.), "Electricity Reform in Europe. Towards a Single Energy Market," Edward Elgar.

Klevorick, A. (1996), "The Race to the Bottom in a Federal System: Lessons from the World of Trade Policy," Yale Law \& Policy Review/Yale Journal on Regulation Symposium: Constructing a New Federalism.

Kovacic, (2007), "Competition Policy in the European Union and the United States: Convergence or Divergence," IESE Conference on the 50th Anniversary of the Treaty of Rome.

Laffont, J.J., Pouyet (2004), “The Subsidiarity Bias in Regulation,” European Economic Review, 88(1-2), pp. 255-283.

Lehman, D.E., Weisman, D. (2000), "The Telecommunications Act of 1996. The "Costs" of Managed Competition,” Kluwer Academic Publishers.

Lehr, W., Kiessling, T. (1999), "Telecommunications Regulation in the United States and Europe: The Case for Centralized Authority," in "Competition, Regulation and Convergence: Trends in Telecommunications Policy Research,” Gillett, S.E., Vogelsang, I. (eds.), Lawrence Elbaum Associates.

Levine, P., Stern. J., and Trillas, F. (2005), "Utility Price Regulation and Time Inconsistency: Comparisons with Monetary Policy,” Oxford Economic Papers 57, pp. 447-478.

Marshaw, J.L., Rose-Ackerman, S. (1984), "Federalism and Regulation," in Eads, G.C., and Fix, M. (eds.), "The Reagan Regulatory Strategy," The Urban Institute Press.

Mookherjee, D. (2006), "Decentralization, Hierarchies and Incentives: A Mechanism Design Perspective," Journal of Economic Literature, June.

Moore, M. C. (2002), "The Issue of Governance and The Role of The Regulator: Lessons from The California Deregulation Experiment," Journal of Industry, Competition and Trade, 2(1/2), pp. 73-90.

Mulligan, C.B., Shleifer, A. (2005), "The Extent of the Market and the Supply of Regulation," The Quarterly Journal of Economics, November, pp. 1445-1473.

Neufeld, J.L. (2008), "Corruption, Quasi-Rents and the Regulation of Electric Utilities," The Journal of Economic History, 68(4), pp. 1059-1097.

Nonnenmacher, T. (2001), "State Promotion and Regulation of the Telegraph Industry, 18451860,” The Journal of Economic History, 61(1), pp. 19-36.

Nuechterlein, J.E., Weiser, P.J. (2007), "Digital Crossroads. American Telecommunications Policy in the Internet Age,” The MIT Press, Paperback Edition.

Oates, W. (1999), “An Essay on Fiscal Federalism,” Journal of Economic Literature, 37, pp. 1120-1149.

Oates, W. (2002), “A Reconsideration of Environmental Federalism,” in List, J. Zeeuw, A. de (eds.), "Recent Advances in Environmental Economics," Cheltenham, U.K., Edward Elgar, pp. 1-32.

Oates, W. (2006), "The Many Faces of the Tiebout Model," in Fischel, W. (ed.), "The Tiebout Model at Fifty: Essays in Public Economics in Honor of Wallace Oates," Cambridge, MA: Lincoln Institute of Land Policy, pp. 28-45. 
Perry, Martin K. (1984), “Scale Economies, Imperfect Competition, and Public Policy,” Journal of Industrial Economics, 32(3), pp. 313-333.

Qian, Y., Weingast, B.R. (1997), "Federalism as a Commitment to Preserving Market Incentives," Journal of Economic Perspectives, 11(4), pp. 83-92.

Riker, W. (1964), “Federalism: Origins, Operation, Significance,” Boston: Little Brown.

Rodden, J., Wibels, E. (2002), "Beyond the Fiction of Federalism -Macroeconomic Management in Multitiered Systems," World Politics, 54, pp. 494-531.

Rodden, J., Rose-Ackerman, S. (1997), “Does Federalism Preserve Markets?,” Virginia Law Review, 83, pp. 1521-1572.

Rubinfeld, D. (1997), “On Federalism and Economic Development,” Virginia Law Review, 83(7), pp. 1581-1582.

Seabright, P. (1996), "Accountability and Decentralisation in Government: an Incomplete Contracts Approach," European Economic Review.

Seabright, P. (1998), “Centralised and Decentralised Regulation in the EU," in "The New Palgrave Dictionary of Economics and the Law,” Macmillan.

Shleifer, A., Vishny, R. (1993), “Corruption,” Quarterly Journal of Economics, 109, pp. 599-617.

Smith, W. (2000), “Regulating Utilities: Thinking about Location Questions,” mimeo.

Spector, D. (2007), "State Aids: Economic Analysis and Practice in the EU," IESE Conference on the 50th Anniversary of the Treaty of Rome.

Stalon, C.G., Lock, R.H.J.H. (1990), "State-Federal Relations in the Economic Regulation of Energy,” Yale Journal on Regulation, 7, pp. 427-497.

Stigler, J., Friedland, C. (1962), “What Can Regulators Regulate," Journal of Law and Economics, 5(1), pp. 1-16.

Sun, J-M., Pelkmans, J. (1995), "Why Liberalisation Needs Centralisation: Subsidiarity and EU Telecoms,” World Economy, 18(5), pp. 635-664.

Teske, P. (2004), "Regulation in the States,” The Brookings Institution.

Tiebout, C. (1956), “A Pure Theory of Local Expenditures," Journal of Political Economy, 64, pp. 416-424.

Tommasi, M., Weischelbaum, F. (2007), "Centralization versus Decentralization: A PrincipalAgent Analysis," Journal of Public Economic Theory, Vol. 9, Issue 2, April 7, pp. 369-389.

Treisman, D. (2000), "Decentralization and Inflation: Commitment, Collective Action, or Continuity,” American Political Science Review, 94(4), pp. 837-857.

Treisman, D. (2006), "Explaining Fiscal Decentralization: Geography, Colonial History, Economic Development and Political Institutions," Commonwealth and Comparative Politics, 44(3), pp. 289-325.

Treisman, D. (2007), "The Architecture of Government. Rethinking Political Decentralization," Cambridge University Press. 
Troesken, W. (1996), "Why Regulate Utilities? The New Institutional Economics and the Chicago Gas Industry.”

Wangensteen, I. (2007), "Power System Economics -The Nordic Electricity Market," Tapir Academic Press.

Weiser, P.J. (2001), "Federal Common Law, Cooperative Federalism, and the Enforcement of the Telecom Act," New York University Law Review, 76, pp. 1692-1767.

Weiser, P.J. (2003), “Cooperative Federalism and Its Challenges," Michigan State DCL Law Review, 3, pp. 727-739.

Wilks, S., McGowan, L. (1995), "Disarming the Commission: The Debate over a European Cartel Office," Journal of Common Market Studies, 32(2), pp. 259-273.

Wolak (2007), "Merger Analysis in Restructured Electricity Supply Industries: The Proposed PSEG and Exelon Merger (2006),” paper presented at POWER Conference, Berkeley, March 2008.

Woroch, G. (1990), "Are Two Regulators Better Than One? Economics of Dual Regulation in Telecommunications,” mimeo. 